\title{
No Accounting For Water: Conflicting Business And Science Viewpoints
}

Julie Plummer, University of Western Australia, Australia

Greg Tower, Curtin University of Technology, Australia

\begin{abstract}
The growing crisis of inadequate global water supply is documented using desert Australia as an exemplar. Policy solutions are advanced advocating improved transparency, clearer communication and better measurement techniques for the physical and monetary attributes of water resources.
\end{abstract}

Keywords: Water, Policy, Education, Australia, Future prospects

\section{INTRODUCTION}

$\mathscr{J}$

he United Nations clearly summaries the importance of this research topic: 'Water is an essential element for life. It is a key element in growing food, generating energy, producing many industrial products as well as in ensuring the integrity of ecosystems and the goods and services they provide. Increasing competition for freshwater between agriculture, urban and industrial use as well as population growth results in unprecedented pressures on water resources, with many countries reaching conditions of water scarcity or facing limits to economic development. Moreover, water quality continues to worsen further limiting the availability of freshwater resources" (2006, p.3).

Water is the essential ingredient for all life on the planet Earth. Yet, the science of measuring water is still in its infancy. We simply do not know how much water is available and how much we use now or will use in the future. Moreover, business and government are faced with constant large scale uncertainty about current usage and future plans and prospects. Colin Chartres, the Director General of the International Water Management Institute (2008) makes the case for urgent research into all aspects of the global water crisis including water availability, access, productivity, quality, health, and the environment.

This paper seeks to review key issues about water and how it is and is not measured. Australia, the driest of Earth's habitable continent, is used as a worthy exemplar (Vardon, Lenzen, Peevor and Creaser, 2007). The urgency of the Australian water crisis is highlighted in Table 1 using a state of Victoria example.

The debate about the allocation of water is thus set in an environment of an ongoing and extensive drought in Australian and growing awareness of the likely permanent effects of climate change. It is now widely accepted that climate change poses a very serious threat to all ecosystems, economies and societies (The Economist, 2009; Savolainen, 2008). Penny Wong, the Australian Federal Minister for Climate Change and Water (2008) bluntly states that climate change is a major threat to Australia and will result in less rain and more droughts. She admits that too much water is currently being allocated and taken from Australian rivers and aquifers. The Australian Federal Government recently commissioned an economist, Ross Garnaut, to summarise the effect of climate change and offer viable solutions. The resultant seminal Garnaut Report (2008) notes the major problems with water supply in Australia are caused by emerging climate change, increased demand due to population increases and uneconomic water pricing policies. A major consultant group, Sinclair, Knight Mertz (2006, pp. 100-101) argue that in Australia:

"water accounting has been developed in an ad hoc fashion ... because [it] ...has been focused primarily on the needs of management and direct customers, rather than the needs of a full range of external users, and the information needs of external users has not been explicitly or systematically explained...Water users, entitlement 
holders, water markets investors, traders and brokers, environmental organisations, auditors, financiers, local governments, researchers, planners and policy formulators have a need for water accounting information that they cannot command from the organisations that could produce this information. Users of water accounting information have the right to expect that accounting information is compiled and reported according to required standards."

Table 1: Drought dominant in 2006-2007

- Drought and its impacts are key themes of the 2006/07 Report.

- Victoria recorded lower than average rainfall for an eleventh consecutive year

- Melbourne experienced its lowest ever rainfall in the year leading up to 15 May 2007.

- Storage levels in 17 of the 19 river basins with major storages finished the year lower than they began. In aggregate, Victoria's major water storages held 2,438,000 ML less water as at 30 June 2007 compared with 30 June 2006 - a decline of 52 per cent.

- Increases in storage levels that normally occur during the winter-spring period did not occur in 2006/07, with aggregate storage levels declining every month until heavy rains late in the year resulted in a small increase.

- Basin inflows in 2006/07 were just 26 per cent of the long-term average, with the majority of basins recording less than 20 per cent of the long-term average streamflow. Inflows into the Murray basin were 3,253,000 ML lower in 2006/07 compared with 2005/06.

- The volume of water diverted for consumptive purposes fell by 24 per cent, or approximately 1,289,000 ML, due to more stringent urban water restrictions, lower seasonal allocations for irrigators and increased bans on diversions from unregulated streams.

- Groundwater use increased by 44 per cent as surface water supplies came under threat. The volume of groundwater used to augment urban supplies doubled compared to 2005/06.

Source: http://www.ourwater.vic.gov.au/monitoring/accounts/06-07/2005-2006_summary_of_key_findings (accessed 11 March, 2009).

This paper first overview the policy issues relating to the 'science' of water including water policy tradeoffs. Then conflicting approaches for measuring water are reviewed. Conflicting stakeholder agendas, water pricing arguments, problems with accounting for water are all discussed and linked to future prospects.

\section{EDUCATING STAKEHOLDERS ABOUT THE SCIENCE OF WATER}

\subsection{The science of water}

In concept, water resource accounting can be thought of as referring to the whole of the terrestrial phase of the water cycle including surface water and groundwater and atmospheric interchanges. Sinclair, Knight Mertz (2006) note the differing overall ways of reporting our water resources: 1) the entire water cycle - combined surface and groundwater resource including atmospheric interchanges; 2) narrower focus on surface water that typically relates to surface river or delivery systems and separates surface water from groundwater; and 3) narrower focus on groundwater that focuses on water in aquifers or groundwater management units and movements in/out of the water entity. Chalmers and Godfrey (2007) argue to best understand the science of water it is essential to know about: water sources, rainfall, desalinated water, water stocks surface, groundwater, atmospheric water including evaporation and transpiration and water flow to households, industry, environment and irrigation users. Figure 1 explains the water inflows and outflows in Australia using 2004-2005 data.

Figure 1 highlights the massive volumes of water under examination. The science encompasses the Earth's atmosphere, the environment and the economy from both a water provider and a water user (stakeholder) perspective. In 2004-2005 from rainfall alone Australia received 2,789,424,000,000,000 (usually labelled as 2, 789, 424 gigalitres (GL)) litres of water. Of that only a small fraction can be captured by water providers (60,436 GL or $2.2 \%$ ) or by directly by the users $68,447 \mathrm{GL}$ or $2.5 \%$ ) and utilised by agriculture, industry and population centres. 
Figure 1: Water supply and use in the Australian economy - 2004-05

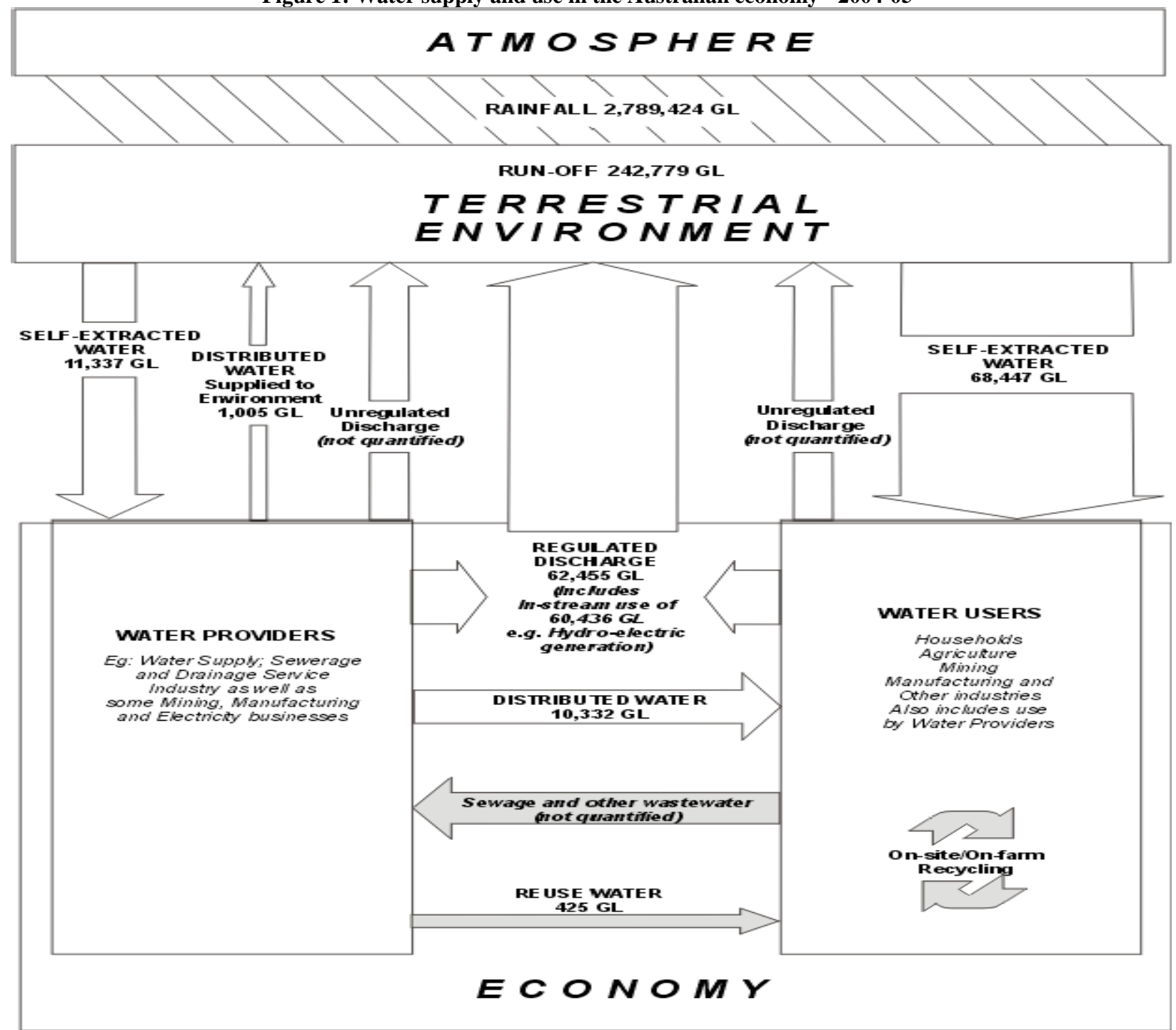

Source: Australian Bureau of Statistics (2009).

http://www.abs.gov.au/AUSSTATS/abs@.nsf/ProductsbyTopic/9F319397D7A98DB9CA256F4D007095D7?OpenDocument

Waterlines (2008, p.13) well summaries the concern about current water policy in Australia. They state:

"Achieving improvements is made difficult by the inadequate specification of the desired environmental and public benefit outcomes. This is primarily due to the shortcomings in water planning processes; in particular, the transparency of trade-offs between environmental and consumptive water uses and the adequacy of the science underpinning water plans. The inability to provide adequate specification of desired outcomes leads to difficulty in monitoring and consequent lower levels of accountability that undermine adaptive management processes".

Overall, there remain many confusing issues related to the science and measurement of water. There are numerous measurement and policy problems. For example, reused water only accounts for $4.1 \%$ of the water distributed by water providers. Moreover, there is a (potentially major) an unknown) unregulated discharge amount not necessarily factored into policy decisions. The next sections explore some of the water science and related policy issues. 


\subsection{Water Policy Trade-offs}

A key issue in water accounting is that it needs to account for multiple dimensions encompassing economic, social, environmental and physical (Chalmers and Godfrey, 2007). Droogers et al (2001) baldly states that water is and will continue to be the major constraining resource in sustainable development in the world. Molden (2004, p.1) argues that policy decision are "often taken without a clear understanding of consequences on all water users". "For too long, we have treated our rivers and groundwater systems as 'magic puddings'; as limitless supplies of water" (Wong, 2008, p.12). Over-allocation of water resources continues to be a key national challenge (Waterlines, 2008).

Two thirds of all water in Australia is used by the irrigation sector (Wong, 2008). Given such figures, the irrigation sector worldwide is under enormous pressure to change their current water practices (Manthrithilake, 2008). Yet there is a dearth of good data on this greatest consuming sector, Sinclair, Knight Mertz (2006, p.220) state "A major information gap is data on the use of rainfall (normally stored in the unsaturated soil profile) for agriculture. This represents a major source of water and is a major contributor to economic benefits. Irrigation water use usually does not include water derived directly from rainfall which reduces the need to take water from rivers or aquifers, thereby skewing the results in wet years."

There are major concerns about the current slant towards agriculture and large scale irrigation projects diverting water away from population centres. This large imbalance towards one sector has major consequences. Waterlines (2008, p.17) bluntly observes that "Protracted drought conditions experienced across much of the country has challenged urban water management and led to severe and protracted water restrictions, both in major cities and regional centres. Urban water shortages in the current drought and the rush to invest in new urban water infrastructure are evidence that supply planning has not delivered the supply security expected by the community". They further posit that there is a strong argument for minimum reliability benchmarks for water supply in the major urban centres. Yet, lacking new water creation initiatives, extra water for urban centres would lessen the amount of water available for agricultural uses. The result is that most major population centres will be required to supplement their water supply with substantial new water sources through the $21^{\text {st }}$ century (Garnaut, 2008). In the past, political expediency has too often ruled the day.

"Settling the trade-offs between ... competing needs should involve judgements informed by best available science, socio-economic analysis and community input" (Waterlines, 2008, p.3). Wong argues that until now "water policy has been derailed by bickering and blame. As a result, progress on many of the important issues has been a case of too little, too late ...Problems like climate change, over-allocation and water shortages don't get fixed by denial, delay or pointing the finger" (2008, p.7).

\section{CONFLICTING APPROACHES FOR MEASURING WATER}

\subsection{Ambiguity and Conflicting Agendas}

The key theme in the above review of the science of water measurement is the surprisingly, continuing large amount of uncertainty and disagreement about what does and does not exist and the related issue of how to best allocate this scarce resource. Clearly there is a strong need for more clarity and agreement from all the key stakeholders. Chalmers and Godfrey (2007) list the key stakeholder groups for water as: 1) water resource and infrastructure providers (water authorities, financing sector and natural environment, 2) recipients of water and water services (agriculture, industry and households), 3) regulatory overseeing functions (government authorities and policy makers).

Godfrey (2008) argues that for appropriate policy making that water must be accounting for broadly encompassing economic, environmental and social elements. The United Nations (2006) distinguishes different types of water flows, namely flows from the environment to the economy, flows within the economy and flows from the economy back to the environment. They posit the first key step toward improved water management is to obtain a good understanding of current patterns of use, supply and pressure with information on sources of demand/supply pressure on water resources, opportunities for improving water productivity, pricing policies and the ultimate 
sustainability of water use. Mertz (2008, pp. 21-28) advances a series of key arguments regarding the benefits of better water data sharing. The items include: declining levels of water data availability and quality; current arrangements are insufficient for sustainable water planning; beneficiaries of improved water data sharing arrangements; national, state and local benefits of improving water data sharing arrangements; improved forecasting and modelling; improved equity and transparency; improved quality standards and learning opportunities; improved decision making in non-water related areas; opportunities for increased distribution of data and collaboration; improved market opportunities; and improved forecasting and planning.

Sinclair Knight Mertz (2006, p.216) nicely summarise the key issuing in stating: "The objective of water supply and use accounting is to provide relevant and reliable public information regarding the economic uses of water, to inform planners, policy makers and the public of the economic benefits being obtained from use of water of the economic effectiveness of current water management policies and regulatory arrangements (including water trading), of the possible economic impacts of changes in water management policies and regulatory arrangements, and conversely of the possible impacts on water resources of changes in the economy."

\subsection{The Reality and Rhetoric of Pricing Water}

"The basic challenge in water resource management is to meet ever-increasing demands for water ... in a sustainable and least-cost way" (Waterlines, 2008, p.1). The United Nations (2006) observe prices charged for water in the market often do not reflect the full economic value of water because of characteristics special and unique to water. These issues include lack of competitive markets, natural monopolistic conditions because of the need for economies of scale for water infrastructure, lack of clear property rights to water and water has a very low weightto-value ratio inhibiting the development of markets beyond local area (United Nations, 2006). Given that water is a collective (public) good and subject to multiple uses the prices charged often do not even reflect its cost of production. Inequitable and inefficient water allocation decisions thus often occur.

The United Nations (2006, p.116) observe "In economic terms, water is an essential commodity so the value (willingness-to-pay) for a basic survival amount is infinite. Once basic needs are met, economic valuation can make an important contribution to decisions about water policy. A commodity has economic value when users are willing to pay for it rather than do without. The economic value of a commodity is the price a person would pay for it (or, on the other side of the transaction, the amount a person must be paid in compensation to part with it). Economic values can be observed when people make a choice among competing products available for purchase... In competitive markets, the process of exchange establishes a price that represents the marginal economic value, that is, the value of the last (marginal) unit sold. In the absence of water markets or where markets function poorly, valuation techniques can be used to estimate the economic value of water."

Waterlines (2008) and many free market economists argue that water trading is a centrepiece of water reform. They feel that water trading will best facilitate efficient water markets, minimise transaction costs, and promote the development of an appropriate mix of water products. More controversially, they also argue that it will protect the needs of the environment and third party interests. The National Water Commission, Murray-Darling Basin Commission and Rural Industries Research and Development Corporation (2007) posit that water trading has helped current industry manage change and even survive as well as being 'critically' important to the establishment of new industries. Yet, Savolainen (2008) worries that the policy 'fixes' for climate change will disproportionally affect low income households. Waterlines (2008) also notes the range of community, government and industry ongoing (yet somewhat differing) concerns with water trading. There is also ongoing angst that environmental concerns will not be a priority area.

Waterlines (2008) lists the following preferred outcomes: economically sustainable and efficient use of water, assurance of sufficient revenue streams for public and private water authorities, enable an efficient market in both urban and rural settings, pricing transparency in a user-pays world, and the avoidance of perverse or unintended pricing outcomes. They note the least progress in Australia has been in the areas of cost recovery and rural and regional water supply. Garnaut (2008) reports takes the 'free market' economic position in stating that governments should have less monopolistic control of water and Australia should instead open up the markets to completion will allow for more efficient allocations via the pricing mechanism. The appropriate price for water remains 
controversial. Priced too low and water is wasted; priced too high and major welfare inequities are created potentially leading to serious social turmoil.

\subsection{Accounting for Water}

Molden (2004) advances the position that a water accounting methodology should be based on a water balance approach that considers inflows and outflows. Sinclair, Knight \& Mertz (2006, p.2) define water accounting as "the application of a consistent and structured approach to identifying, measuring, recording and reporting information about water". Whereas Chalmers and Godfrey (2007, p.59) more broadly define water accounting by linking to users by stating it is "a systematic process of identifying, measuring, monitoring and communicating information about water-related transactions, transformations and events to allow informed judgements and decisions about the allocation of scare resources". Molden (2004) also feels that water accounting should consider all components of water balance and classify them according to use and productivity. Sinclair, Mertz and Knight (2006, pp.14-15) acknowledge that water accounting goes beyond mere reporting when they note "from a philosophical perspective, it is recognised that while water accounting practices will reflect the prevailing water management regime, it can also influence the management regime through the methodical presentation of information and associated analysis and help bring about beneficial change".

Godrey $(2008$, p.15) argues that "water accounting has the potential to radically transform water policy, and the resourcing of the water industry. This change will be achieved only through fundamental changes to the nature and integrity of data underpinning decision-making and by presentation of this data in a format, context and timeframe that facilitates effective, informed decision-making".

Waterlines (2008, p.14) states that "water resource accounting is the application of a consistent and structure approach to identifying, measuring, recording, aggregating and reporting water information including its occurrence, extraction, diversion, storage, trade, use, loss and discharge". Sinclair Knight and Mertz (2006) nominates key parameters for water accounting. First, water accounting does not change who manages water. Second, water accounting will reflect events that occur. Third, water accounting will not decide what will happen; it will enable reporting of what has happened. Finally, engineering, accounting, statistical and scientific experts will define guidelines and standards associated with identification and measurement of water accounting

Yet, achieving these goals has proven to be very difficult. There remain huge open questions:

- $\quad$ How should we account for water?

- $\quad$ Should such measures be primarily scientific and volume-style measures?

- $\quad$ Alternatively, should such measure be more focussed on monetary dollar values?

- How can such figures be reliable, especially given the complications of measuring the very complex cycle of water?

- $\quad$ How can such figures be relevant? Comparable? Understandable to all the key stakeholder groups?

The United Nations (2006) admits that different countries will use different approaches for measuring water. For instance, the Peoples Republic of China measures water supply accounting and related environmental impacts different than most of the other parts of the world by placing a much greater focus on the impact on the population (Zhu et al, 2004). The United Nations (2006) acknowledges that countries facing severe water scarcity often start with the compilation of basic information on the hydrological water balance which then feeds into the asset accounts. In contrast, countries facing problems with water pollution often start with emission accounts then hybrid supply and use tables which allow for the formulation of policies aimed at reducing the emission to water resources.

Sinclair, Knight, Mertz (2006) notes the development of water accounting in Australia is in an immature phase and is being developed in an ad-hoc fashion. They then advocate usage of a chart of water accounts that define what type of information must be gathered and recorded and the level that the information element is to be aggregated and reported as well as who prepares the water accounting reports. They feel that such accounts should as a minimum contain data on the scope of the report, opening water balances, inflows, outflows, and end of period 
water balances. This task remains arduous given that there is not even an Australian standard for water meters (Waterlines, 2008).

In Australia, the federal government passed the Water Act 2007 which gives the Bureau of Meteorology the responsibility for compiling and maintaining water accounts for Australia and also to issue national water information standards. However, there is still much work to be done. Marsden, Jacobs and Associates (2005) note one of the biggest current problems is the measurement of extraction (diversion) of water. They argued that errors in measurement of extraction from rivers by the largest diverters are outweighing all other errors. They further argue that standards are inadequate, and the methods and procedures are inconsistent. Molden (2004) states the crucial need for better estimation of evaporation and transpiration. He also calls for greater use of water performance indicators especially to measure: 1) depleted fractions (such as depletion divided by net inflow); 2) process fraction (such as process depletion divided by total depletion); 3) and productivity of water (such as productivity divided by net inflow). An excellent critique is provided by Sinclair, Mertz and Knight (2006) in their large scale stock take of water in Australia. Their key findings and criticisms are shown in Table 2.

Overall, the Table 2 criticisms provide a mixed message. Sinclair Mertz Knight (2006) note the scientific techniques range from very sophisticated to minimal. Charts of account data are often non-existent or filled with inconsistencies. Water information systems are often inadequate. Reporting of water data is better for physical measures and worse for environmental concerns. In general, there are ongoing concerns about the ability to well meet the greater demand for 'better' water accounting.

\subsection{Advocating a Global Water Accounting Solution}

The United Nations is making active moves in the goal of creating better water accounting. They have tasked the United Nations Statistics Division (UNSD) to create a System of Environmental and Economic Accounting for Water (SEEAW). The UN argues that SEEAW provides an appropriate conceptual framework for organizing the hydrological and economic information (in what they believe is a coherent and consistent manner). The SEEWA document advocates the generation of information in five key categories. These are: 1) physical supply and use tables (expressed in quantities) as well as emission accounts (expressed in scientific terms or monetary terms); 2) hybrid and economic accounts (expressed in monetary terms); 3) asset accounts (expressed in monetary terms); 4) quality accounts (usually expressed in scientific terms); and 5) valuation accounts (expressed in monetary terms) (United Nations, 2006).

A great deal of prior work and consensus exists for the first three categories: physical supply, hybrid and economic accounts, and asset accounts. Vardon et al (2007) observes that the most progress has been made in the accounting for 'physical supply and use' in volume terms. However, even the UN (2006) admits that the last two categories (accounting for quality and valuation) are far more controversial and problematic. Governments and water authorities are starting to use this UN framework as the model for water accounting. However, development is still in the nascence phase. The next two sub-sections further explains the problems of measuring quality and valuation of water resources.

\section{Striving to Measure the Quality of Water}

The two most difficult concepts in the above framework are 'quality' and 'valuation. For water quality there are two main issues with its implementation: the definition and measurement of water quality classes. The United Nations (2006) SEEWA framework documents notes that water quality is generally defined for a specific concern with little standardisation of concepts or definitions or aggregation methods. Quality describes the current state of a certain water body in terms of certain characteristics, which are called "determinands" (United Nations, 2006). Under the SEEWA framework, the general structure of the quality accounts is the same as that of the water asset accounts; the only difference is the addition of the quality dimension, which describes (in quality terms). An Australian example shows the range of possible quality indicators ranging from the level of nutrients to temperature changes (see Table 3). Each indicator may have its own scientific measurement to best communicate the status of the water quality. 
Table 2: Critique of Water Accounting in Australia

\begin{tabular}{|c|c|}
\hline 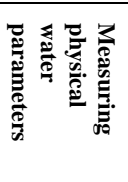 & $\begin{array}{l}\text { - Spatial location of measurement points (eg river gauges, bores, meters, etc) is known to a high level of accuracy. } \\
\text { - Measurement of river levels and flows has well established standards and practices commonly in use; no commonly used standards and } \\
\text { practices for measurement of piped flow. } \\
\text { - Well established standards/procedures, maintained and published by the Bureau of Meteorology for measurement of rainfall and evaporation; } \\
\text { no organisations indicated they directly measured transpiration. } \\
\text { - Techniques for identifying farm dams and charting their surface areas were of mixed quality and expensive. }\end{array}$ \\
\hline 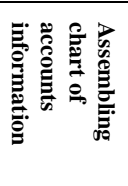 & $\begin{array}{l}\text { - Management units are still changing and evolving, particularly for groundwater. } \\
\text { - Water service providers generally assembled and reported extensive water information in relation to delivery systems and sewerage systems for } \\
\text { which they are responsible. However water information for irrigation drainage systems was less common and almost non- existent for } \\
\text { stormwater drainage systems. Water reporting on environmental sites is at a very early stage of development. } \\
\text { - Volumes in major storages at any time are readily available. Capacities (but not volumes at a particular time) in minor storages (farm dams etc) } \\
\text { are available in some areas, and river and channel volumes are generally not available. }\end{array}$ \\
\hline 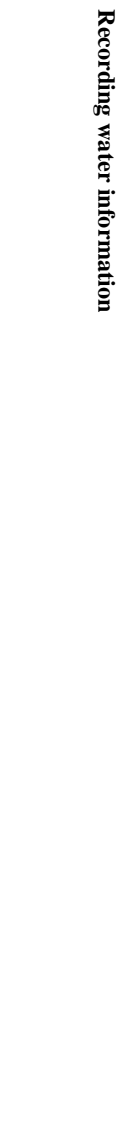 & 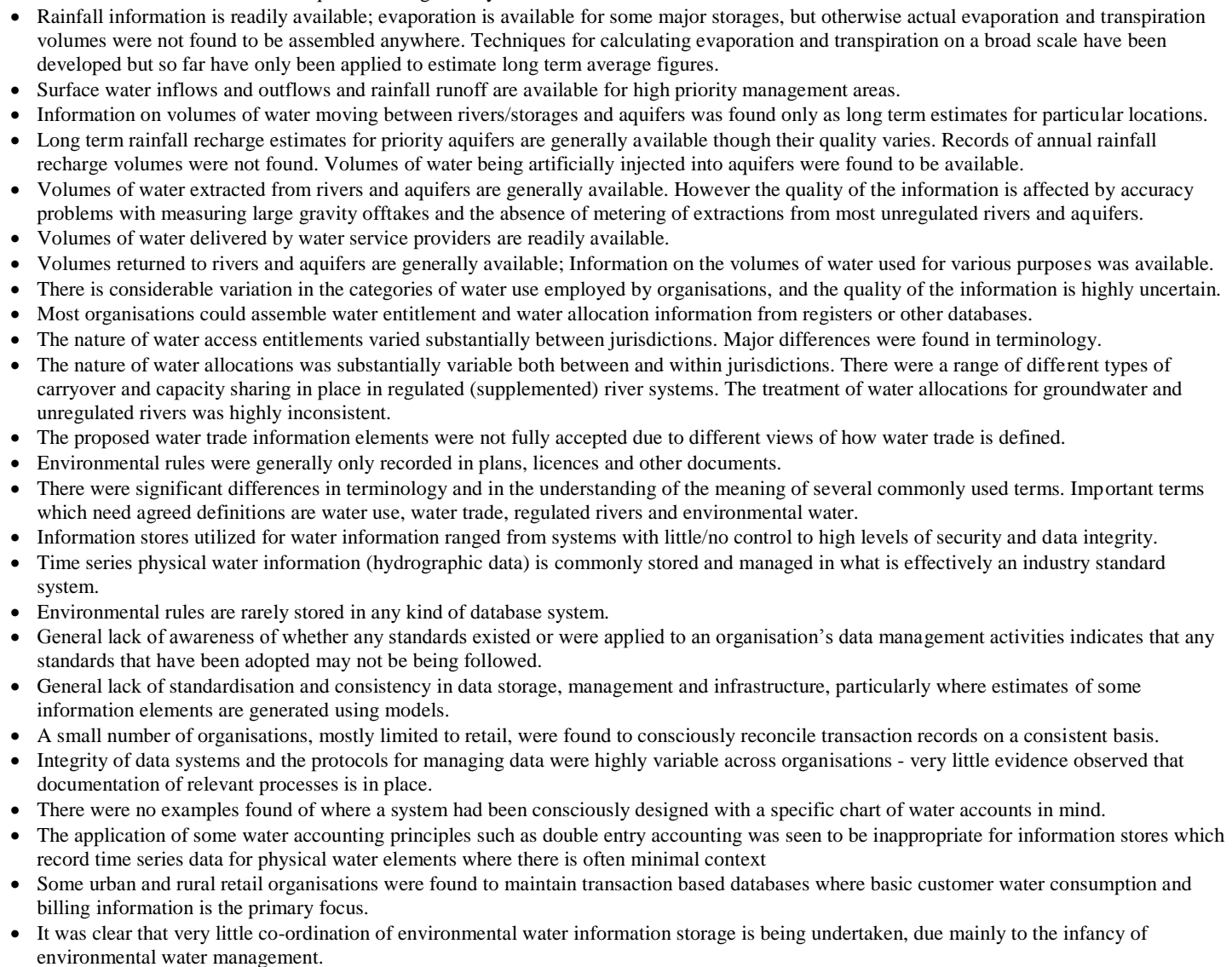 \\
\hline 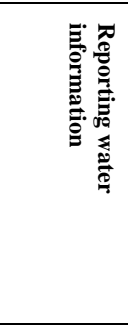 & $\begin{array}{l}\text { - Organisations are increasingly preparing reports containing water accounting information and reporting requirements are to meet the } \\
\text { information demands of regulators/public. } \\
\text { - No organisations indicated they were capable of generating the proposed water cycle report for any physical water entities. } \\
\text { - Most organisations indicated that they could generate the proposed surface water reports (commonly called water balance reports) for most } \\
\text { physical entities for which they are responsible (river basins, delivery systems, sewerage systems) at little additional cost. } \\
\text { - Most relevant organisations could with some investment generate water entitlement, water allocation and water trading reports. } \\
\text { - Terms, definitions, and use categories employed by the ABS are frequently different to those used by other organisations. } \\
\text { - No organisations currently produce anything like the proposed environmental rules reports. Generally the information is not held in any kind of } \\
\text { database, being mostly in plans and compliance reports. } \\
\text { - With the exception of the Australian Bureau of Statistics information on water use, there is currently no attempt to roll up (sum) information to } \\
\text { state and national levels. }\end{array}$ \\
\hline 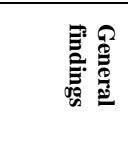 & $\begin{array}{l}\text { - Many organisations indicated that the increasing demands for reports by regulators and the public was putting them into 'reporting overload'; } \\
\text { need for common standard reporting procedures } \\
\text { - The personnel who are currently preparing water information may not have appropriate skills, understanding and experience to undertake some } \\
\text { aspect of water information management. } \\
\text { - Participating personnel are concerned about significant cost burdens on their organisations with increased demand of water accounting. }\end{array}$ \\
\hline
\end{tabular}
Source: Sinclair, Mertz and Knight (2006, pp. 93-98). 
Table 3: Selected Water Quality Indicators

\begin{tabular}{|c|c|}
\hline Indicator & Potential impacts from changes \\
\hline Turbidity & $\begin{array}{l}\text { - Increased water surface temperature due to changes in light penetration } \\
\text { - Increased sedimentation can cause changes in breeding patterns of bottom gravel dwelling organisms } \\
\text { - } \quad \text { Suspended particles can cause suffocation in some fish, adversely affect fishing, aquaculture and tourism } \\
\text { - Increased cost of treating affected water }\end{array}$ \\
\hline Nutrients & 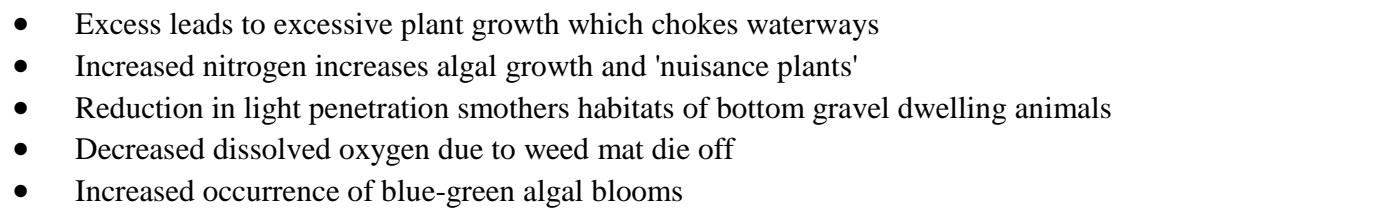 \\
\hline Temperature & $\begin{array}{l}\text { - } \quad \text { An increase or decrease affects fish breeding (spawning) } \\
\text { - } \quad \text { Changes in algae occurrences }\end{array}$ \\
\hline Salinity & 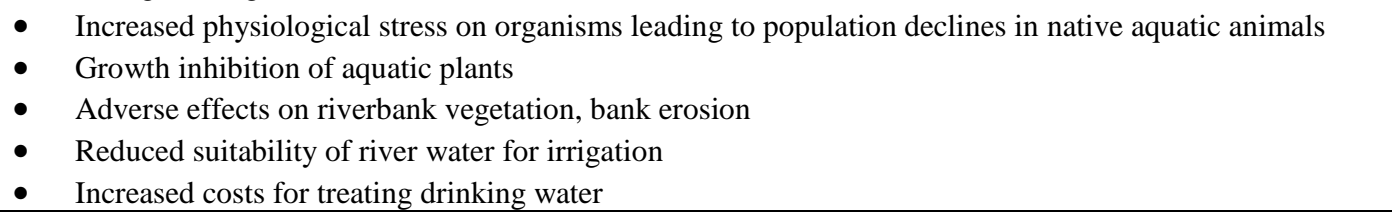 \\
\hline
\end{tabular}
Source: National Land and Water Resources Audit, Australian Catchment, River and Estuary Assessment (2002).

A similar if more detailed system is used in France. For instance, in communicating the quality accounts for rivers the French government provided comparative tables that show five categories over a range of years. These categories ranged from a $1 \mathrm{~A}$ classification of the health of the river (best), falling to $1 \mathrm{~B}, 2,3$ and $\mathrm{NC}$ (not classified, worst). The description of water according to quality was available for two years and the figures are comparable as they are obtained from the same assessment methods (Sinclair, Knight Mertz, 2006).

There are potential solutions being voiced. For example, the SEEWA framework argues for the use of two key indices (River Quality Generalised Index (RQGI) and the Pattern Index (PI).

"The River Quality Generalised Index (RQGI) aggregates water quality over river basins. Water quality accounts could be used to measure the efficiency of water management programmes that often exist at the basin level. The results of measures taken or the expenditures incurred should be readable through an improvement of the water quality. It is therefore important to be able to aggregate water quality over river basins".

"The Pattern Index measures the variance in the quality classes of the stretches that underlies a particular RQGI score for a river basin. It allows for differentiating between basins where water is of a uniform quality and basins where it results from certain "hotspots" or occasional exceeding. Improving the quality of a water body that results from a "hotspot" requires less effort than purifying water that is permanently polluted by numerous chemicals." (United Nations, 2006, SEEWA Framework, p.109).

There remain important problems with 'quality' accounting. Whilst most water quality assessments evoke a form of the 'rule of the worst' (i.e. the rule of always choosing the lowest or most detrimental value from a certain set); the United Nations (2006) notes that there are large differences in both the number and choice of determinands used. A concern is that the number of common determinands is very low, moreover, different countries use different ones. The choice of determinands is often the outcome of a scientific, practical, economical and political compromise. Some important determinands cannot be reliably and affordably monitored (United Nations, 2006). Given this lack of standardisation, the ability to compare is greatly lessened.

\section{Striving to Measure the Value of Water}

'Valuing' the water is the other problematic element of the SEEWA water accounting framework. The United Nations well summaries the problem "Because water is a bulky commodity and the costs of transporting and storing water are often high, the value of water is determined by local and regional site-specific characteristics and 
options for use. For example, the value of water as an input to agriculture will often vary a great deal by region because of differing factors that affect production costs and product value, including soil, climate, market demand, cost of inputs, etc. In addition, the timing of water availability, water quality and reliability of supply are also important determinants of water value. Consequently, the value of water can vary enormously within a country, even for the same sector" (2006, p.114).

The United Nations further notes the following quite formidable problems with valuing water including: the incomplete nature of available data and expensive, the site-specific nature of water value and the overall methods and assumptions are not standardized leading to high uncertainty. They list three economic approaches that lead to quite different measures of water valuation:

- $\quad$ Marginal value, the price the last buyer would be willing to pay for one additional unit.

- $\quad$ Average value, the average price that all buyers would be willing to pay, including a portion of consumer or producers' surplus, which is the maximum amount that each buyer would be willing to pay, even though he is not actually charged that price.

- $\quad$ Total economic value, a measure of total economic welfare that includes consumer surplus and producer surplus, that can be used to estimate average value.

Arguably, there are solutions to many of these issues. The international accounting framework created by the International Accounting Standards Board can be adopted to water accounting with some modifications. The concept of the core financial statements can be maintained: financial position statement (balance sheet), income statement and a financial cash flow statement. The accounts can be modified for instance in some cases assets are replaced with water in storage; revenue is replaced with inflows of water; expenses can be expressed with outflows of water. Whilst appropriate revenue and expenditure could be stated in terms of increases and decreases in water allocations or water access entitlements. Moreover, water allocations under entitlements and commitments of water under environmental rules can be considered to be unmet liabilities, which are reduced when the water is taken or supplied (Sinclair, Mertz and Knight, 2006).

\section{LOOKING TOWARDS THE FUTURE}

By 2050 it is estimated that Australia's population will grow from 21 million to 33 million people (Wong, 2008). The demand for water will clearly rise over the next decades. Wong (2008, p. 9) states "We need to understand the implications of climate change for our farmers, cities, towns and rivers. This demands sound water resource planning to inform tough water sharing and investment decisions, decisions that are required to ensure that all needs are catered for in the face of reduced water availability and -in many instances - increased population". Water reform initiatives need to include education as well as more dialogue with industry, agriculture and science (Furner, 2008).

The call for transparent and open accounting for water sounds like an oxymoron. Who could argue against such sensible and needed principles? However, there are major political crosswinds and turbulence. Water, is a limited resource, thus water allocation becomes a zero-sum game. Some stakeholders will win with a more 'efficient and equitable' reallocation, yet others will lose and potentially lose badly with related economic devastating consequences. Moreover, not all stakeholders are equally adapt or financial able to garner their political lobbying power. How is policy to be made for a product with static perhaps even decreasing supply but ever growing demand? Governments in the past have in a sense have bankrupted future generations by over-allocating water rights. Global warming, climate change and the resultant deep drop in water catchment areas are finally making governments face the harsh and unpalatable reality of this unsustainable policy.

Waterlines (2008) nicely summarises the continuing key problems to optimal water reform as being the need for: better understanding of the relationship between water and the environment; better knowledge to jointly manage surface water and groundwater; addressing the over-allocation and/or overuse of water resources; ongoing different interpretations of the concept of sustainable levels; significant improvements in knowledge, policies and practices of land use activities; improved water plans; governments to complete and actualise policies in a consistent manner; and significant improvement in monitoring and compliance of water resources. 
How should solutions be brought about? The Australian federal government, perhaps strongly motivated by the increasing effects of drought and climate change in Australia, appears to be speeding up the reform process. By 2010, they plan to have developed national standards for water market accounting, recourse accounting wand environmental water accounting and related information systems (Waterlines, 2008). Furner (2008) notes four key policy initiatives by the Australian government as the pursuit of a fundamental reform agenda encompassing: 1) taking action on climate change, 2) using water wisely, 3) securing water supplies, and 4) supporting healthy rivers. The hope is that "poor-planning, over-allocation and under-investment can be avoided so that future water shortages may be minimised" (p.21). There are also new ways of increasing water supply including greater usage of desalination plants, more recycling of 'grey' water, more storm water harvesting, less wastage due to seepage and evaporation, and more water restrictions including possible total bans on water gardens. Molden (2004) further observes the importance of developing standardised widely accepted procedures for performing water audits.

Mertz (2008, p.31) makes an important point that there will be winners and losers to a new system of clearer transparency. "There are benefits to not sharing data, including retaining ownership, regulating uses and misuse, and minimising risk to the agency or its reputation or policy". Other problems for water reform in Australia that need to be overcome include the: 1) lack of water professionals with technical expertise, 2) government interference at the state and local levels via the use of 'policy bans' on certain urban water supply options, 3) lack of clarity and agreement of the specific reforms needed, and 4) lack of clear accountability (Waterlines, 2008).

Certain key voices argue for more clarity for the business of water. PriceWaterhouseCoopers (2006) and Garnaut (2008) feel that water reform should include key principles including: 1) clearly defined water rights with exclusive ownership, 2) future flexible water rights allocation responsive to new scientific insights, 3) security levels established that acknowledges the variability of supply, 4) evolution of clearly defined rules of acceptable behaviour, 5) more reliable and timely flow of information, 6) clear administrative processes for trade and enforcement, 7) goal of low and clear transaction costs, and 8) few as possible limitations on market participation. Garnaut (2008, p. 375) advances the economists" solution "With a well-designed and comprehensive water market in place, price signals will reflect the scarcity value of water across rural and urban Australia. It can reasonably be expected that households, businesses and other consumers will modify their water use accordingly".

In summary, solutions are clearly needed and the status quo is blatantly unacceptable. All stakeholder groups need to acknowledge that "water is currently managed as if it were worthless instead of the life-sustaining, valuable, and increasingly scarce resource that it is" (Clark, 2007, p.1).

\section{AUTHOR INFORMATION}

Julie Plummer, from the School of Plant Biology, Faculty of Natural and Agricultural Sciences at the University of Western Australia, has considerable experience in the physiology of crops, breeding and selection. Her expertise is in examination of environmental and genetic influences and their manipulation to improve commercial yield or value and she is very concerned about the changing availability of water for agriculture and landscapes. She has published 112 scientific articles including 65 in refereed journals, 30 in the last 5 years. She has won an Award of Excellence for her Contributions to Horticulture and an Australian Teaching Award.

Greg Tower, his doctorate and research interests are in the realm of financial and international accounting. He is especially interested in the communication of a broad range of economic, social and environmental firm activities to stakeholders. Greg is a FCPA and has published over 120 research articles in many business and accounting journals. He also has successfully supervised over 30 doctorate, masters and honours students. For the last six years he has served as a research professor for the School of Accounting at Curtin University of Technology in Perth Australia.

\section{REFERENCES}

1. Australian Bureau of Statistics (accessed 11 March, 2009).

http://www.abs.gov.au/AUSSTATS/abs@.nsf/ProductsbyTopic/9F319397D7A98DB9CA256F4D007095D 7?OpenDocument 
2. $\quad$ Chalmers, K. and Godfrey, J.M. (2007). Drop by Precision Drop, InTheBlack, 77(10), pp. 59-61.

3. Chartres, C. (2008). Research with Impact: A New Thrust Forward, Water Figures: Turning Research into Development, International Water Management Institute (2008). Issue 4, p.3.

4. Clark, E.H. (2007), Water Prices Rising Worldwide, Earth Policy Institute, http://www.globalpolicy.org/socecon/gpg/2007/0307waterprices.htm, accessed 17 March 2009.

5. Droogers, P., Salemi, H.R. \& Mamanpoush, A.R. (2001). Exploring Basin-Scale Salinity Problems Using a Simplified Water Accounting Model: The Example of Zayandeh Rud Basin, Iran, Irrigation and Drainage, 50, 335-338.

6. $\quad$ Furner, J. (2008), Water Policy for the Future, Public Administration Today, April-June, pp. 19-21.

7. Godrey, J. (2008), Accounting for Change, Public Administration Today, April-June, pp. 5-6.

8. Garnaut, R. (2008). The Garnaut Climate Change Review, Final Report, Cambridge University Press: Port Melbourne, Victoria, Australia.

9. International Water Management Institute (2008). Water Figures: Turning Research into Development, Issue 4, 1-8.

10. Manthrithilake, (2008). KnowledgeHubs: Meeting the Water Sector Needs of the Asia-Pacific Region, Water Figures: Turning Research into Development, International Water Management Institute (2008). Issue 4, 5-6.

11. Marsden, Jacobs and Associates (2005). Audit of Murray Darling Basin Cap Data Management Systems, Authors.

12. Mertz, S.K. (2008). The Need for Improved Water Data and Water Data Sharing, Waterlines Occasional paper No. 4. A Series of Works commissioned by the National Water Commission on Key Water Issues, Canberra, Australia: National Water Commission.

13. Molden, D. (2004). Accounting for Water Use and Productivity, Report, International Irrigation Management Institute: Columbo, Sri Lanka

14. National Water Commission, Murray-Darling Basin Commission and Rural Industries Research and Development Corporation (2007). The Economic and Social Impacts of Water Trading, Jointly commissioned by the National Water Commission, Murray-Darling Basin Commission and Rural Industries Research and Development Corporation.

15. PriceWaterhouseCoopers (2006), A Discussion Paper on the Role of the Private Sector in the Supply of Water and Waste Water Services, Department of the Prime Minister and Cabinet, Canberra.

16. Savolainen, S. (2008), Promoting a New Future of Environmentally Sustainable Social Housing, Public Administration Today, April-June, pp. 15-18.

17. Sinclair, Knight, Mertz (2006). Stocktake and Analysis of Australia's Water Accounting Practice, Final Report, Sinclair Knight Merz: Tatura Victoria, Australia.

18. The Economist (2009, January 3-9). Troubled Waters, Volume 290 (8612).

19. United Nations (2006). System of Environmental-Economic Accounting for Water, United Nations Statistical Division: New York, New York.

20. Vardon, M., Lenzen, L., Peevor, S. \& Creaser, M. (2007). Water Accounting in Australia, Ecological Economics, 61, pp. 650-659.

21. Victoria Water Accounts (accessed 11 March, 2009). http://www.ourwater.vic.gov.au/monitoring/accounts

22. Waterlines (2008). Update of Progress in Water Reform, A Series of Works commissioned by the National Water Commission on Key Water Issues, Canberra, Australia: National Water Commission.

23. Wong, P. (2008), Water for the Future, Public Administration Today, April-June, pp. 7-14.

24. Zhu, Z., Giordano, M., Ca, X. \& Molden, D. (2004). The Yellow River Basi: Water Accounting, Water Accounts, and Current Issues, 29(1), 2-10. 